\title{
INLUENCE OF LOADING CYCLE ASYMMETRY AND LONG-TERM THERMAL EXPOSURE ON FATIGUE CRACK GROWTH RATE IN MARTENSITIC P91 AND P92 STEELS
}

\author{
${ }^{1}$ Ladislav KANDER, ${ }^{2}$ Jan KANDER, ${ }^{1}$ Marek DOBIÁŠ, ${ }^{1}$ Petr JONŠTA \\ ${ }^{1}$ MATERIAL AND METALLURGICAL RESEARCH Ltd., Ostrava - Vitkovice, Czech Republic, EU, \\ ladislav.kander@mmvyzkum.cz \\ ${ }^{2}$ Brno University of Technology, Faculty of Mechanical Engineering, Brno, Czech Republic, EU.
}

https://doi.org/10.37904/metal.2021.4127

\begin{abstract}
The paper deals with the effect of different loading cycle asymmetry and long-term thermal exposure on fatigue crack growth rate in P91 and P92 steels used primarily for components in USC powerplants. Testing was performed using $\mathrm{C}(\mathrm{T})$ specimens. Fatigue crack growth was measured in II. stage of crack growth described by Paris law from both sides using optical microscope. Loading cycle asymmetry effect was assessed for each steel grade before the thermal exposure and then compared with state after the long-term thermal exposure.
\end{abstract}

Keywords: Fatigue crack growth rate, loading cycle asymmetry, long-term thermal exposure, P91 and P92 steels

\section{INTRODUCTION}

Martensitic P91 and P92 steels with $<12$ wt. \% of Cr are creep-resistant materials used mainly for construction of boilers and piping used in USC powerplants. To ensure safe operation of these components, it is necessary to meet wide range of requirements given by standard [1]. This includes chemical analysis, mechanical properties determined by tensile test, Charpy impact test, metallography analysis of the microstructure. Besides these basic test methods, it is useful to acknowledge and evaluate fatigue and fracture behavior caused by dynamic loading from steam coming through pipes at high pressure and temperature. Main goal of this paper is to evaluate and compare an effect of different loading cycle asymmetry $(R=0.1, R=0.6)$ and long-term thermal exposure at $5000 \mathrm{~h}$ and $600{ }^{\circ} \mathrm{C}$ for $\mathrm{P} 91$ and $650{ }^{\circ} \mathrm{C}$ for P92 on fatigue crack growth rate of observed steels.

\section{APPARATUS AND TEST METHOD}

Two steam pipelines made of P91 (wall thickness $35 \mathrm{~mm}$ ) and P92 steels (wall thickness $90 \mathrm{~mm}$ ) have been used for investigation. The comprehensive analysis including assessment of mechanical properties, yield strength at elevated temperatures, fracture properties and fracture toughness, microstructure and creep properties was done [2,3].

Chemical composition of the steels under investigation is given in the Table 1. Typical chemical composition based on Cr-Mo-V alloying elements combination in the case of P91 steel and similar composition with substitution of part of Mo by W for P92 steel is presented. Small addition of boron for P92 can be seen from Table 1.

Experimental programme was realized on servomechanical testing machine MTS $100 \mathrm{kN}$. For crack growth rate measurement, optical crack measurement was used. Two different loading cycle asymmetries were studied to evaluate effect of loading on crack growth rate. All tests were performed at room temperature with frequency $15 \mathrm{~Hz}$. Pre-cracking the specimens and subsequent fatigue crack growth rate measurement was 
performed at load ratio $R=0.1$ and $R=0.6$ according to ISO 12108 [3]. Stress amplitude was chosen so that it would cover the interval of stress intensity factor range approximately $\Delta \mathrm{K}=10-30 \mathrm{MPa} \cdot \mathrm{m}^{1 / 2}$.

Table 1 Chemical composition of the steels under investigation (wt. \%)

\begin{tabular}{|c|c|c|c|c|c|c|c|c|c|c|c|}
\hline & C & $\mathrm{Mn}$ & Si & $\mathbf{P}$ & $S$ & $\mathrm{Cr}$ & v & Mo & $\mathrm{Ni}$ & $\mathrm{Cu}$ & $\mathrm{Ti}$ \\
\hline P91 & 0.10 & 0.42 & 0.29 & 0.012 & 0.004 & 8.29 & 0.19 & 0.93 & 0.18 & 0.13 & $<0.005$ \\
\hline \multirow[t]{2}{*}{ P92 } & 0.10 & 0.41 & 0.20 & 0.013 & 0.004 & 8.74 & 0.18 & 0.48 & 0.21 & 0.12 & $<0.005$ \\
\hline & $\mathrm{Nb}$ & w & Co & As & $\mathrm{Sb}$ & Sn & $\mathrm{N}$ & Alsol. & Albond & $\mathbf{A l}_{\text {total. }}$ & B \\
\hline P91 & 0.079 & 0.009 & 0.010 & 0.013 & 0.001 & 0.007 & 0.052 & $<0.001$ & 0.002 & 0.002 & - \\
\hline P92 & 0.050 & 1.66 & 0.010 & 0.020 & 0.002 & 0.005 & 0.052 & $<0.001$ & 0.001 & 0.001 & 0.002 \\
\hline
\end{tabular}
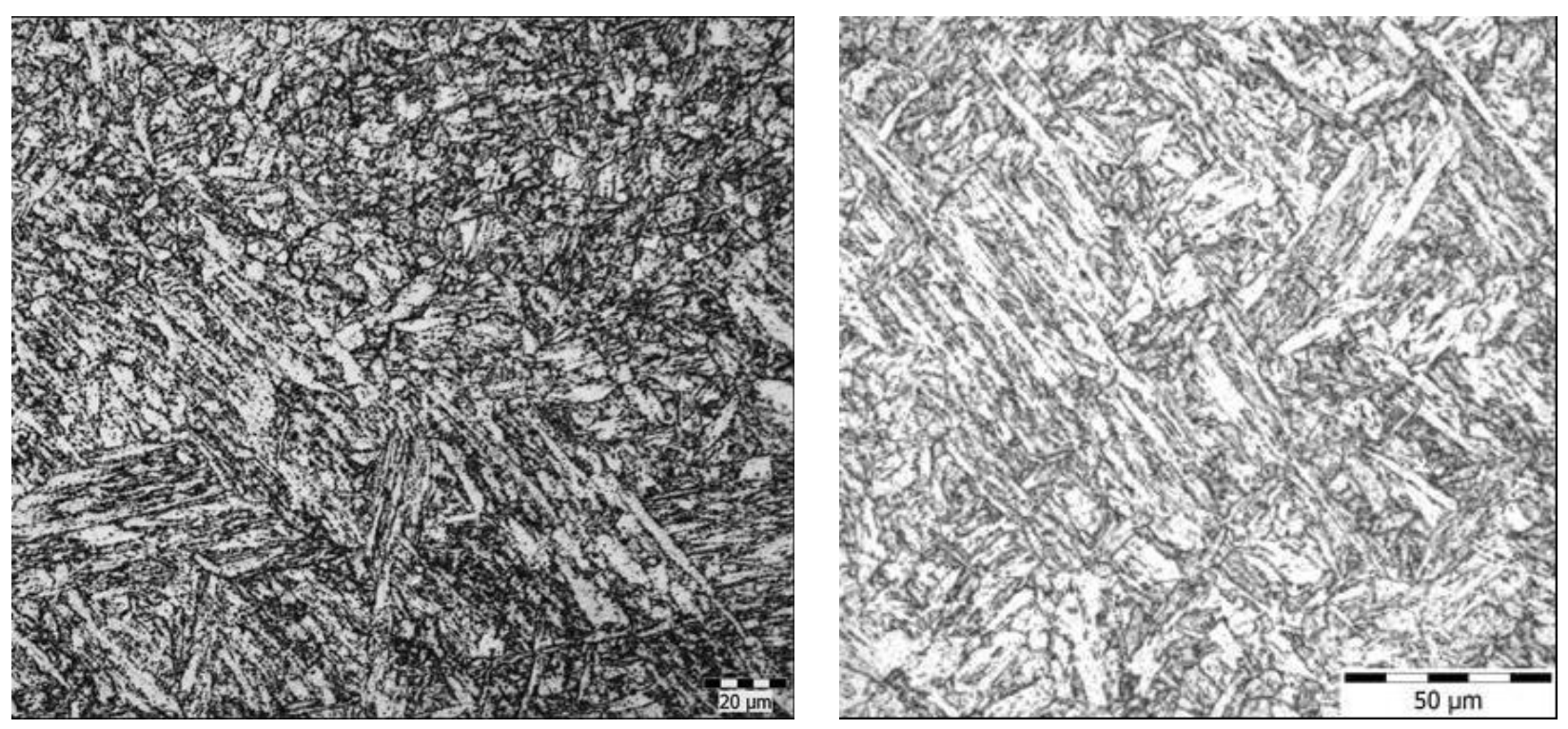

Figure 1 Comparison of microstructures of the steels under investigation, P91 left, P92 right

Table 2 Actual mechanical properties of the steels under investigation

\begin{tabular}{|c|c|c|c|c|}
\hline pipeline steel & $\begin{array}{c}\mathbf{0 . 2 \%} \text { offset yield } \\
\text { strength } \\
\mathbf{R}_{\mathbf{p 0 . 2}} \\
(\mathbf{M P a})\end{array}$ & $\begin{array}{c}\text { Tensile strength } \\
\mathbf{R}_{\mathbf{m}} \\
(\mathbf{M P a})\end{array}$ & $\begin{array}{c}\text { Elongation } \\
\mathbf{A} \\
(\%)\end{array}$ & $\begin{array}{c}\text { Reduction of } \\
\text { area } \\
\mathbf{Z}\end{array}$ \\
\hline P91 & 594 & 726 & 23.3 & 74.7 \\
\hline P92 & 486 & 647 & 26.2 & 72.4 \\
\hline
\end{tabular}

Effect of long-term thermal exposure at operating temperature at 5000 hours and $600{ }^{\circ} \mathrm{C}$ for P91 steel and 5000 hours and $650^{\circ} \mathrm{C}$ for $\mathrm{P} 92$ steel on fatigue crack growth rate has been studied too.

Microstructures of both steels are shown in the Figure 1 and mechanical properties are summarized in the Table 2. Metallographic analysis was performed on a sample parallel to the sampling plane at the pipe surface and was focused on analysis of microstructure and possible microstructural changes in the case of long-term thermal exposed specimens. 
Actual mechanical properties evaluated on outer surface of both pipelines are shown in the Table 2. Due to actual state of the microstructure (tempered martensitic structure) is possible to achieve relative high ratio of yield stress to tensile strength especially in the case of P91 where this ratio is nearly 0.82 and good plastic properties (elongation and reduction of area).

\section{TEST RESULTS AND DISCUSSION}

As a tested materials, P91 and P92 martensitic steel alloys were used. All tests were performed using CT specimen with $B=6 \mathrm{~mm}$ and $W=25 \mathrm{~mm}$ Every measurement was done with constant frequency of $15 \mathrm{~Hz}$. Two different loading cycle asymmetries were used $(R=0.1, R=0.6)$. Crack length was measured via optical microscope from both sides. Pre-cracking the specimens and subsequently fatigue crack growth rate measurement was performed at load ratio $R=0.1$ according to ISO 12108 [4]. Stress amplitude was chosen so that it would cover the interval of stress intensity factor range approximately $\Delta K=10-30 \mathrm{MPa} \cdot \mathrm{m}^{1 / 2}$. Same loading cycle asymmetries were applied on specimens exposed to $5000 \mathrm{~h}$ and $600{ }^{\circ} \mathrm{C}$ for P91 and $5000 \mathrm{~h}$ and $650{ }^{\circ} \mathrm{C}$ for $\mathrm{P} 92$ of long-term thermal exposure.

The relationship between fatigue crack growth rate and stress intensity factor was introduced by Paris [5]. Paris law is visualized on log-log plot and expressed by equation (1).

$\frac{d a}{d N}=C \cdot \Delta K^{m}$

where:

$$
\begin{aligned}
& a-\text { crack length }(\mathrm{mm}) \\
& N \text { - number of cycles (1) } \\
& C, m \text { - constants depended on material, environment and stress ratio (1) } \\
& \Delta K \text { - stress intensity factor range }\left(\mathrm{MPa} \cdot \mathrm{m}^{1 / 2}\right)
\end{aligned}
$$

As it can be observed from Figures 1 and 2, the experiments confirmed that higher value of asymmetry parameter $R$, which is defined as $R=\sigma_{\min } / \sigma_{\max }$, causes faster crack growth in P91 steel before (Figure 2) and after the exposition (Figure 3). As the value of $\Delta K$ raises due to crack growth, the difference between crack growth rate for $R=0.6$ and $R=0.1$ starts to diminish and at around $\Delta K$ the difference is very minor.

Figures 2 and 3 show crack growth rate in P91 and P92 before and after long-term thermal exposure $\left(5000 \mathrm{~h}, 600{ }^{\circ} \mathrm{C}\right.$ for P91 and $5000 \mathrm{~h}, 650^{\circ} \mathrm{C}$ for P92). In both figures it can be observed that the differences in crack growth rate are very minor - almost none for both steels. P91 and P92 are both creep-resistant steels that are designed to withstand loading under elevated temperatures for at least 100000 hours, if not more. This means that the thermal exposition would have to be much longer in order to cause major differences in microstructure and fatigue crack growth rate of abovementioned steels.

There are very few data in the literature on the kinetics of crack growth of the investigated steels, most of the work focuses on the evaluation of creep crack growth rate evaluation under operating conditions. A detailed literature search of this issue is given in [6]. As the operating condition is not only creep conditions and fatigue loading also occurs material behavior under Paris law should be taking into account in design procedure of similar components. Effect of temperature on fatigue crack growth in P92 at $\mathrm{R}=0.1$ has been studied in [7] whereas effect of long term aging $\left(20000\right.$ hours at $\left.550{ }^{\circ} \mathrm{C}\right)$ on crack growth in P91 at different temperature has been investigated in [8]. 


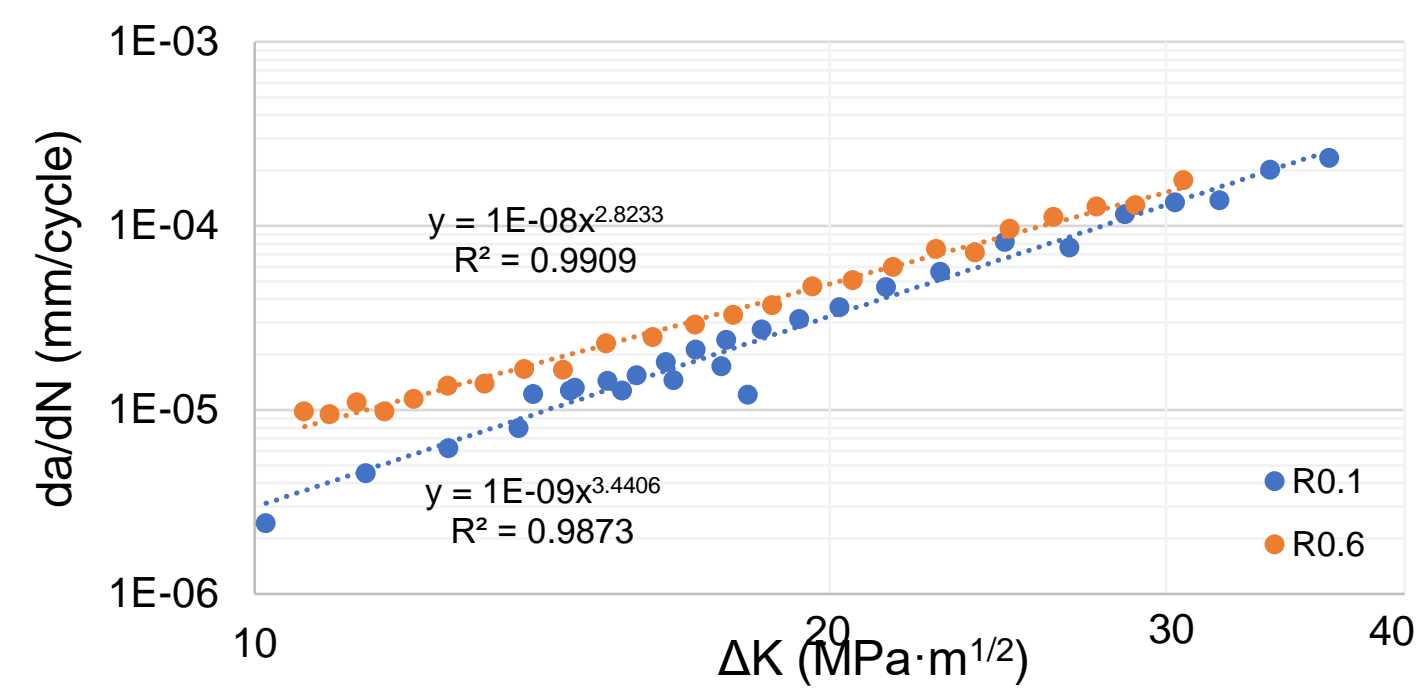

Figure 2 Influence of loading cycle asymmetry on crack growth rate in P91 before exposition

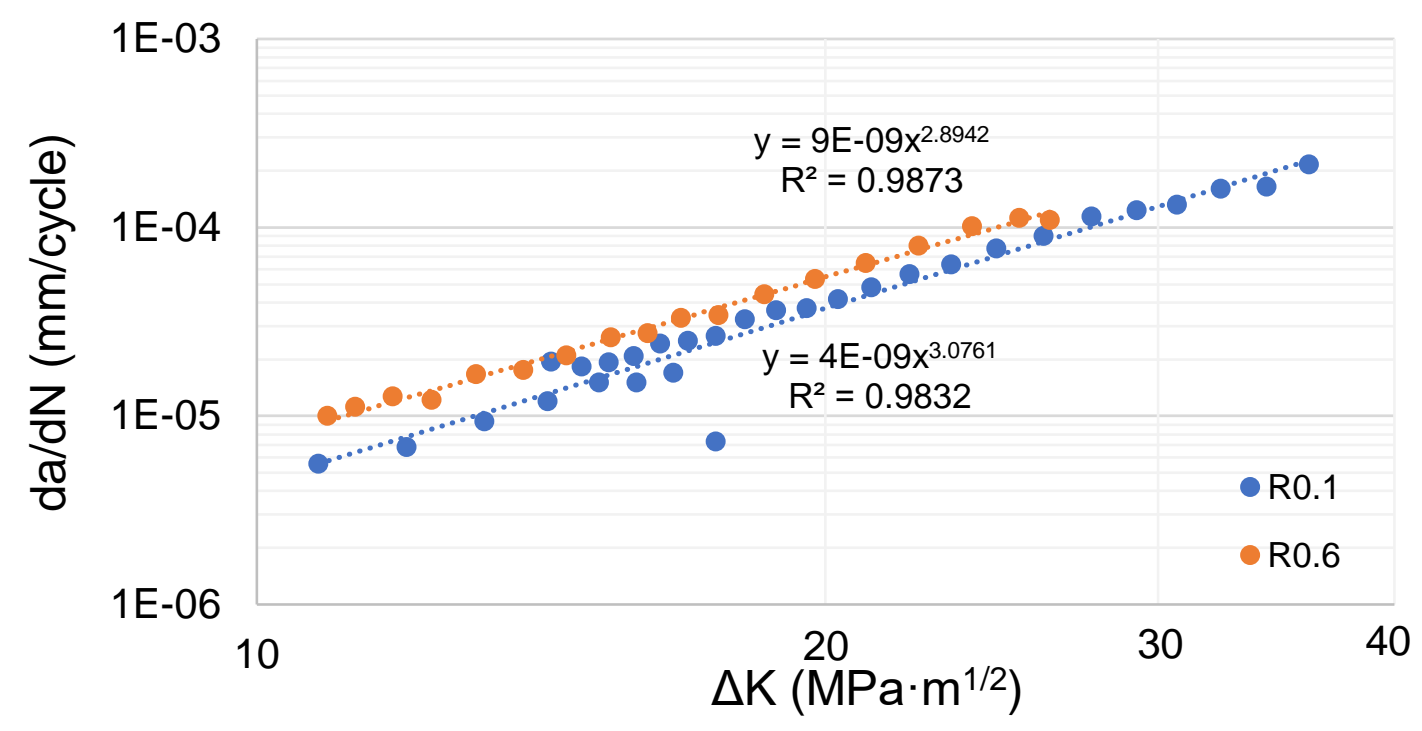

Figure 3 Influence of loading cycle asymmetry on crack growth rate in P91 after exposition

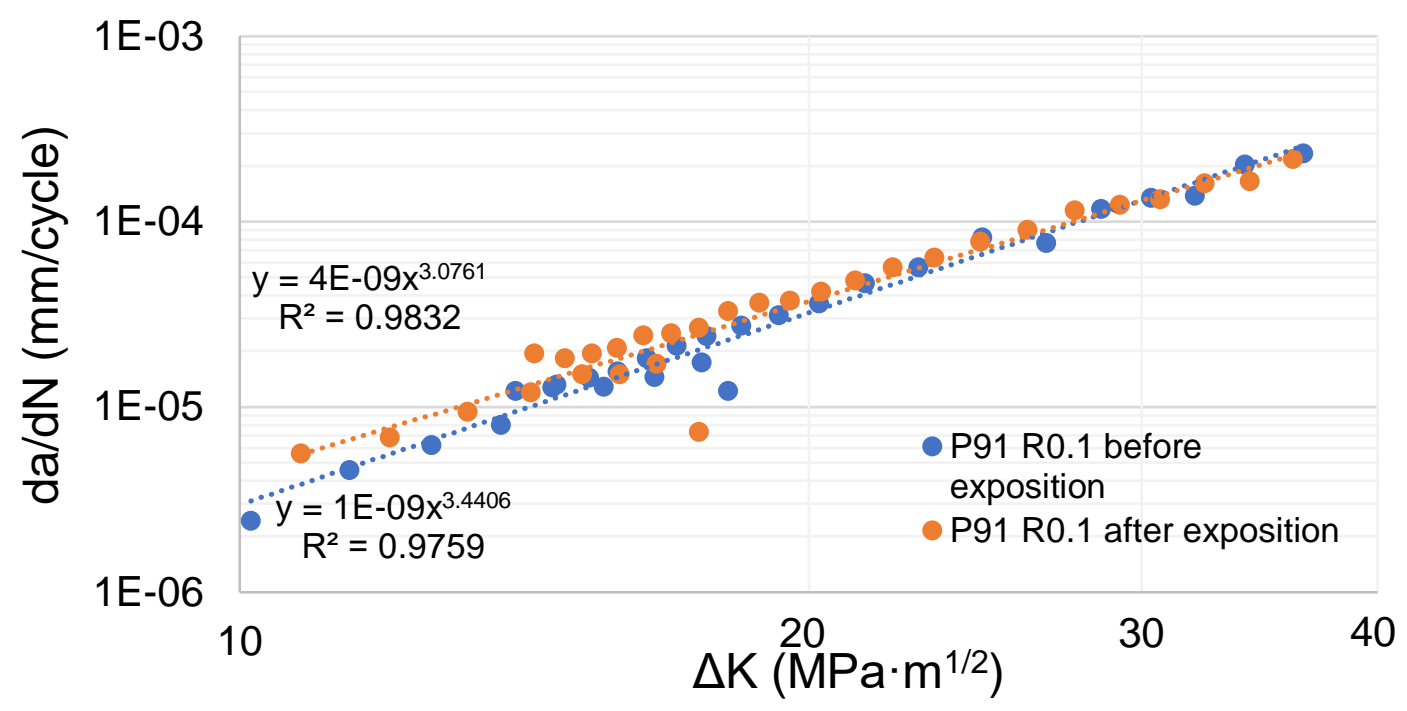

Figure 4 Crack growth rate in P91 before and after exposition (both for $R=0.1$ ) 


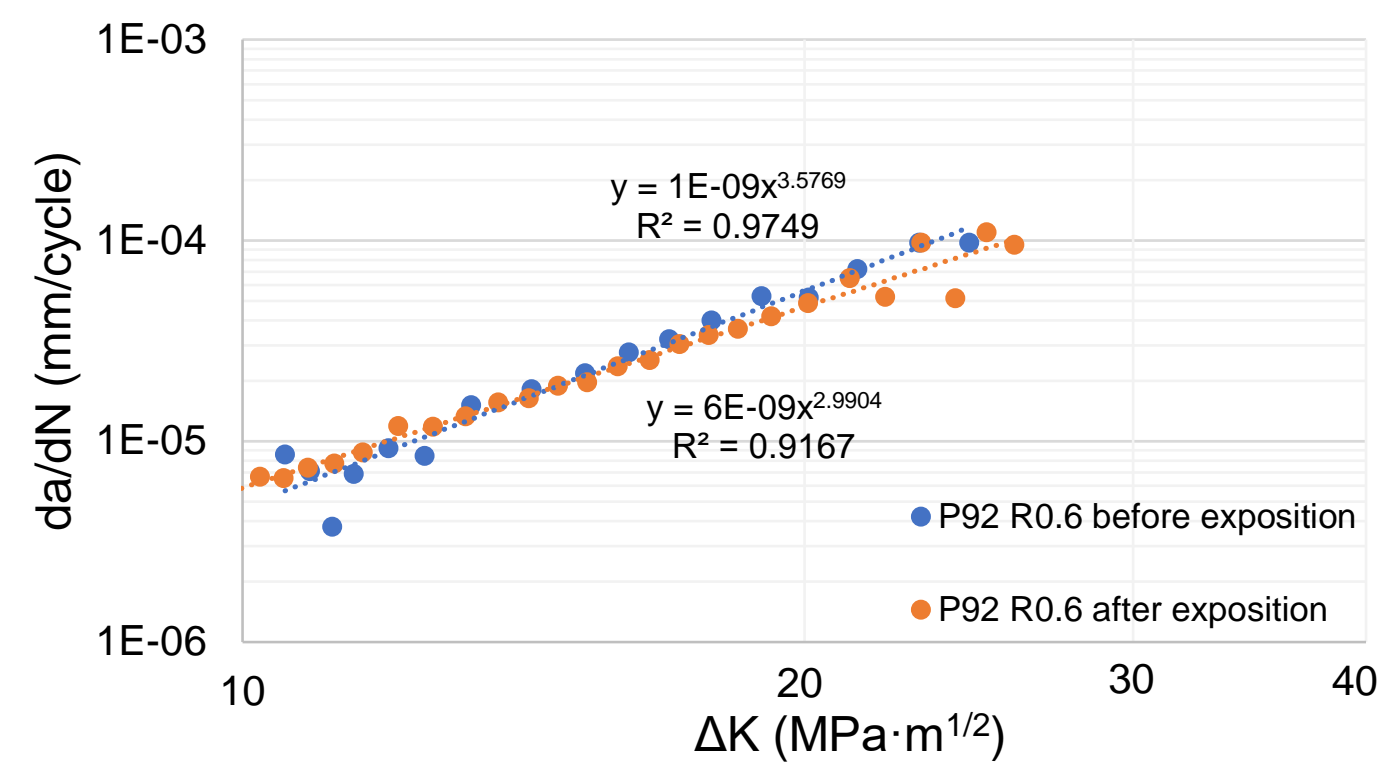

Figure 5 Crack growth rate in P92 before and after exposition (both for $R=0.6$ )

\section{CONCLUSIONS}

In terms of presented experimental work, two pipeline steels P91 and P92 were analysed. The comprehensive assessment included the analysis of mechanical properties, microstructure examination, evaluation of fracture behaviour.

In this work attention was paid mainly to measuring of crack growth rate at various conditions and thermomechanical state [5] including both virgin state and long-term thermal exposed state for 5000 hours at working temperatures. Only small changes have been observed in crack growth rate properties at defined cycle asymmetry $\mathrm{R}=0.1$ and $\mathrm{R}=0.6$ for $\mathrm{P} 92$ steel, where this effect is negligible. On the other hand, for P91 steel effect of cycle asymmetry is more significant and is equal about $30 \%$ at $\Delta K=20 \mathrm{MPa} \cdot \mathrm{m}^{1 / 2}$. Obtained results are in very good agreement with similar experimental work $[7,8]$, at higher asymmetry crack grows a little bit faster especially in the case of P91 steel. This effect is determined by higher value of constant $C$ in Paris law equation. Same crack growth rate was measured compared to work [7], where also temperature effect om P92 crack growth rate was evaluated. Effect of long-term thermal exposure at working temperatures is shown in the Figures $\mathbf{4}$ and $\mathbf{5}$. Both figures clearly show that long-term thermal exposure did not affect crack growth rate for both of steels. Those results are in very good agreement with the fact that no microstructural changes due to this long-term thermal exposure have been found in work [9]. The both steels P91 and P92 are creep-resistant steels that are designed to withstand loading under elevated temperatures for at least 100 000 hours. This means that the thermal exposition would have to be much longer in order to cause significant differences in microstructure and fatigue crack growth rate behavior of abovementioned steels. Similar results were obtained for both steel and for both cycle asymmetry and shows good microstructural stability at given condition if the exposure. On the contrary the crack growth rate for aged material $\left(20000\right.$ hours at $550{ }^{\circ} \mathrm{C}$ ) was found to be higher than that on unaged in work [8] due to precipitation of Laces phase. Presence of this Laves phase in both steel investigated in this work was not confirmed after 5000 hours in study [9] on the other hand specimens with 15000 hours exposure will be able for experimental work in the next year.

Further work focused on evaluation of fracture toughness, actual creep properties and small punch tests as well as long-term thermal exposure up to 15000 hours is continuing within the frame of project. 


\section{ACKNOWLEDGEMENTS}

This paper was created in the Project No. TK010201603 "Complex procedures of material engineering to ensure the safe operation of innovated blocks of fossil power plants." funded by the Technology Agency of The Czech Republic (TACR)

\section{REFERENCES}

[1] ČSN EN 10216-2+A1. Bezešvé ocelové trubky pro tlakové účely - Technické dodací podmínky - Část 2: Trubky z nelegovaných a legovaných ocelí se stanovenými vlastnostmi při zvýšených teplotách. Praha: Česká agentura pro standardizaci, 2020.

[2] STEJSKALOVÁ, Š., DORAZIL, O., FILIP, M., KOSŇOVSKÁ, J., ROŽNOVSKÁ, G. Projekt Théta - Komplexní postupy materiálového inženýrství k zajištěni bezpečného provozu inovovaných blokủ klasických elektráren, zpráva T-60/2018. Ostrava: Materiálový a metalurgický výzkum (in Czech), 2018.

[3] STEJSKALOVÁ, Š., DORAZIL, O., FILIP, M., KOSŇOVSKÁ, J., ROŽNOVSKÁ, G. Projekt Théta - Komplexní postupy materiálového inženýrství k zajištění bezpečného provozu inovovaných bloků klasických elektráren, zpráva T-66/2019. Ostrava: Materiálový a metalurgický výzkum (in Czech), 2019.

[4] ČSN ISO 12108. Kovové materiály - Zkoušení únavy - Metoda růstu únavové trhliny. Praha: Česká agentura pro standardizaci, 2019.

[5] PUGNO, N., CIAVARELlA, M., CORNETtI, P., CARPINTER, A. A generalized Paris' law for fatigue crack growth. Journal of the Mechanics and Physics of Solids. 2006, vol. 54, pp. 1333-1349.

[6] KANDER, J. Kinetika šírení únavových trhlin v ocelích P91 a P92 [online]. Brno, 2021. Diplomová práce, Vysoké učení technické v Brně, (in Czech): Available from: https://www.vutbr.cz/studenti/zav-prace/detail/131983.

[7] BYEONG, S.L., CHAN, S.J., YOUNG, T.K. Effect of temperature on fatigue crack growth in P92 steel. Metals and Materials International. 2003, vol. 9, no. 6, pp. 543-547.

[8] BABU, M.N., SWAIN, S.K., DUTT, B.S., VENUGOPAL, S., SASIKALA, G. Influence of long term ageing on fatigue crack growth behaviour of P91 steel at different temperatures. [online] In: Srivatsan T.S., Imam M.A., Srinivasan R. (eds) Fatigue of Materials III. Cham: Springer, 2014, pp. 155-167. Available from: https://doi.org/10.1007/978-3-319-48240-8 11

[9] JUNEK, M., HORVÁTH, J., SVOBODOVÁ, M., HORVÁTH, L. Komplexní postupy materiálového inženýrství k zajištění bezpečného provozu inovovaných bloků klasických elektráren. Zpráva UJP 1967. (in Czech). Praha, 2020. 